\title{
Estudo experimental do uso de um antagonista do receptor da glicoproteína Ilb/IIla das placentas na prevenção de tromboses em microanastomoses vasculares
}

\author{
An experimental study on the use of an antagonist of the platelet glycoprotein \\ IIb/IIla receptor in the prevention of thrombosis in \\ vascular microanastomoses
}

MÁRCIO ISSAMu OIDE

\section{RESUMO}

O autor comparou, experimentalmente, a eficácia da droga abciximab, um antagonista do receptor da glicoproteína llb/ IIla das plaquetas, na prevenção da trombose nas microanastomoses arteriais em ratos Wistar. Utilizou 20 animais, dos quais 10, do grupo controle, receberam solução salina e 10 receberam abciximab, na concentração de 0,8mg/ $\mathrm{kg}$, injetados na veia femoral. Trinta minutos após a administração da solução salina ou abciximab, todos os animais foram submetidos ao mecanismo provocador de trombose vascular da artéria femoral do lado oposto ao utilizado para administração da droga, por meio de um trauma externo promovido por aparelho IMPACTOR, desenvolvido pela New York University para padronização de lesão da medula nervosa, o que padronizou a lesão arterial. Todos os animais foram submetidos à microanastomose vascular com mononáilon 10-0, em pontos separados, no local do trauma externo. Foram realizados testes para analisar a perviabilidade vascular da artéria femoral no período de 10, 20 e 30 minutos após o término da anastomose. Após este período, todas as artérias femorais submetidas às microanastomoses foram ressecadas e analisadas em microscopia óptica para avaliar a presença de formação de trombos. Após a análise estatística dos dados, o autor concluiu que o uso do antagonista do receptor da glicoproteína Ilb/llla das plaquetas diminuiu a incidência de tromboses nas microanastomoses vasculares.

Unitermos - complexo glicoprotéico GPIlb/llla de plaquetas/ efeitos de drogas; trombose/prevenção, microanastomose cirúrgica; artéria femoral; ratos wistar.

\section{SUMMARY}

The author has experimentally compared the efficacy of the platelet glycoprotein $/ / b / / 1 / a$ receptor antagonist (abciximab) in the prevention of platelet aggregation and thrombosis in microvascular surgery using rat models. Twenty rats were used: ten rats were used as a control group and received saline; tem rats received abciximab $0.8 \mathrm{mg} / \mathrm{kg}$ administered in the femoral vein. After thirty minutes following administration, all rats underwent vascular thrombosis of the opposite femoral artery through an external trauma promoted by IMPACTOR, a device developed by the New York University to serve as a model of the spinal cord injury and the arterial damage. All rats were submitted to microvascular anastomoses using mononylon 10-0 and separated suture at the site of the external trauma. Patency tests were performed on femoral arteries 10, 20 and 30 minutes after microanastomoses. All femoral arteries were removed for pathological studies to detect presence or absence of thrombus generation at the microanastomoses. After statistical analyses, the author concluded that the use of the platelet glycoprotein IIb/IIla receptor antagonist (abciximab) avoided platelet aggregation and thrombosis in microvascular surgery.

Key words -platelet glycoprotein IIb/IIla complex / drugs effect; thrombosis / prevention, microvascular surgery; femoral artery; Wistar rats. 


\section{INTRODUÇÃO}

A microcirurgia vascular avançou muito nas últimas quatro décadas, desde a sua introdução por JACOBSON; SUAREZ em 1960. Tal fato deve-se não apenas à melhoria na confecção dos instrumentos microcirúrgicos, equipamentos ópticos e fios microcirúrgicos, como também ao aperfeiçoamento no treinamento dos cirurgiões. Conseqüentemente, houve uma diminuição nos índices de tromboses nas microanastomoses, mas, ainda hoje, esta é uma das principais causas de insucesso nas reconstruções microcirúrgicas.

Para a prevenção das tromboses, tem-se utilizado substâncias antitrombóticas, como a heparina, os antiagregantes plaquetários, como o ácido acetilsalicílico, e os antagonistas do receptor da glicoproteína Ilb/llla.

A heparina inibe de forma indireta a trombina, graças à sua ligação reversível com o anticoagulante antitrombina III. Este último é um inibidor natural dos fatores de coagulação sangüínea ativados (ROSENBERG; ROSENBERG 1984 e SALZMAN et al. 1980). O complexo heparina-antitrombina III potencializa o efeito antitrombina, por meio da inativação da trombina e dos fatores de coagulação XIla, Xla, IXa e Xa.

O ácido acetilsalicílico, associado ou não ao dipiridamol, reduz significativamente a incidência de formação de trombos (BARNATHAN et al. 1987 e FUSTER et al. 1993), porém a eficácia dele como agente antiagregante plaquetário deve ser considerada pequena. $\mathrm{O}$ ácido acetilsalicílico inibe a formação de tromboxane $\mathrm{A}_{2}$ das plaquetas e conseqüentemente a ativação de outras plaquetas graças ao bloqueio irreversível da enzima ciclo-oxigenase (JANG et al. 1992).

Embora a trombina seja um agonista potente da agregação plaquetária, tanto a heparina quanto o ácido acetilsalicílico são agentes antiagregantes plaquetários fracos, com limitado mecanismo de ação, pois outros agonistas como o colágeno, a adenosina difosfato, a adrenalina e a serotonina, podem ativar as plaquetas independentemente da trombina e da via da ciclooxigenase, pela ativação de receptores da glicoproteína IIb/IIla (JANG et al. 1992).

Para prevenir a trombose de maneira eficaz, seria necessária ou a administração de várias substâncias para bloquear cada via de ativação plaquetária, ou a administração de uma substância específica, um antagonista do receptor da glicoproteína Ilb/Illa para o fibrinogênio, presente nas membranas das plaquetas e responsável pela agregação plaquetária. COLLER et al. (1991) descrevem um novo anticorpo monoclonal murínico, denominado 7E3, contra o receptor de fibrinogênio da glicoproteína Ilb/Illa das plaquetas como agente antitrombótico. Este anticorpo monoclonal 7E3, abciximab, tem sido largamente utilizado na área de cardiologia para a prevenção das complicações cardíacas isquêmicas nos pacientes de alto risco submetidos à angioplastia transluminal coronária percutânea ou arterectomia (EPIC investigators 1994, LEFKOVITS et al. 1997, ELLIS et al. 1998).

Por acompanharmos as atividades clínico-cirúrgicas do Grupo de Mão do Instituto de Ortopedia do Hospital das Clínicas da Faculdade de Medicina da Universidade de São Paulo e

\section{INTRODUCTION}

The vascular microsurgery has advanced over the last four decades, since its introduction by JACOBSON and SUAREZ, in 1960. The progress was due either to the improvement of microsurgical devices, optical instruments and microsurgical wires, or the improvement in surgeons training. As a result, there was a decline in the incidence of microanastomoses thrombosis rates, although it still represents one of the main causes of failures in the microsurgical reconstructions.

For preventing thromboses, antithrombotic agents like heparin, antiplatelets like acety/salicylic acid, and glicoprotein IIb/IIla receptor antagonists have been used.

Heparin inhibits thrombin indirectly thanks to its reversible binding with the anticoagulant named antithrombin III. Antithrombin III is a natural inhibitor of the activated clotting factors (ROSENBERG; ROSENBERG 1984 and SALZMAN et al. 1980). The complex heparin-antithrombin III enhances the effect of antithrombin through the inactivation of thrombin and clotting factors as XIla, XIa, IXa and Xa.

The acetylsalicylic acid, associated or not to dipiridamole, may reduce thrombi incidence and formation significantly (BARNATHAN et al. 1987 and FUSTER et al. 1993). However its efficacy as an antiplatelet agent is low. The acetylsalicylic acid inhibits the thromboxane A2 generation from platelets and the subsequent activation of other platelets thanks to the irreversible blockade of the cyclooxigenase enzyme (JANG et al. 1992).

Although thrombin is a potent agonist of the platelet aggregation, either heparin or acetylsalicylic acid is weak antiplatelet agents. They have a limited activity because other agonists as collagen, adenosine diphosphate, adrenaline and serotonin can activate platelets aside from thrombin and the cyclooxigenase pathway, by activating platelet glycoprotein I/b/ Illa receptors (JANG et al. 1992).

In order to avoid thrombosis effectively we should give a number of drugs to block each pathway of the platelet activation or a single substance, like an antagonist of the glycoprotein IIb/ IIla receptor for the fibrinogen, which is present in platelets membranes and is responsible for the platelets aggregation. COLLER et al. (1991) described a new murine monoclonal antibody (7E3) against the fibrinogen receptor of the platelet glycoprotein IIb/IIla as an antithrombotic agent. This monoclonal antibody 7E3, abciximab, has been widely used in cardiology for preventing heart ischemic complications in high-risk patients underwent percutaneous transluminal coronary angioplasty or arteriotomy (EPIC investigators 1994, LEFKOVITS et al. 1997, ELLIS et al. 1998).

Because we are interested in preventing and decreasing the incidence of complications of the microsurgical procedures related to the thrombosis of vascular microanastomoses, we had the incentive to develop and create an experimental model with the objective of testing new drugs and procedures. In addition, we usually follow the clinical and surgical activities from Institute of Orthopedics of São Paulo University. 
interessados em tentar prevenir e diminuir ainda mais o índice de complicações dos procedimentos microcirúrgicos relacionados à trombose de microanastomoses vasculares, ficamos estimulados em desenvolver e criar um modelo experimental com o objetivo de testar novas drogas e procedimentos.

Apesar de haver poucos relatos na literatura relacionados à aplicação do anticorpo murínico contra o receptor da glicoproteína IIb/IIla na prevenção de trombose em microanastomoses vasculares (STOCKMANS et al. 1997), consideramos que a utilização desta droga poderia modificar e diminuir o índice de trombose em situações de maior complexidade.

Com o objetivo de utilizar o anticorpo monoclonal murínico 7E3, abciximab, na prevenção de trombose em procedimentos microcirúrgicos, decidimos testá-lo, em modelo experimental em ratos, para avaliar a sua eficácia.

\section{MATERIAL E MÉTODOS}

Foram utilizados, no presente estudo, 20 ratos da linhagem Wistar, fornecidos pelo biotério do Instituto de Ortopedia e Traumatologia da Universidade de São Paulo, pesando em média 352.37gramas (máximo de 417g. e mínimo de 260g.), correspondendo à idade aproximada de cinco meses de vida. Os ratos foram divididos em dois grupos de 10 animais cada, que passaremos a denominar de I e II.

Técnica cirúrgica

Em todas as cirurgias foram realizadas pelo mesmo cirurgião. Todos os animais foram submetidos à anestesia com solução de cetamina (ketalarâ) na dose de $80 \mathrm{mg} / \mathrm{kg}$ associado com solução aquosa a $2 \%$ de cloridrato de 2-(2,6-xilidino)-5,6-dihidro$4 \mathrm{H}$-1,3-tiazina (rompunâ) na dose de 3,2mg/kg de peso corporal administrado por via intraperitoneal. Cada animal foi posicionado em decúbito dorsal na tábua de dissecação. Realizada a tricotomia das coxas e região inguinal ventralmente e anti-sepsia com álcool etílico (Figura 1). Procedemos à incisão de três centímetros de extensão, somente atravessando a pele na região inguinal entre o abdômen e a coxa. Divulsionamos o coxim gorduroso inguinal e individualizamos o feixe vásculo-nervosofemoral e dos vasos epigástricos. Após a dissecação do feixe vásculo-nervoso-femoral na sua bainha perivascular, foram identificados: a artéria centralmente, a veia medialmente e o nervo lateralmente (Figura 2). Realizada a hemostasia rigorosa com bisturi elétrico bipolar com o auxílio do microscópio cirúrgico. $\mathrm{Na}$ veia femoral isolada, foi introduzido um cateter de polietileno $n^{\circ} 24 G$ (NIPROâ) através do qual foram injetados 0,8mg/kg de abciximab (ReoProâ) no grupo II e solução salina a 0,9\% no grupo I (Figura 3). Foram realizados os mesmos procedimentos para a dissecação do pedículo na pata oposta.Com a artéria femoral isolada, foi colocada uma placa de material plástico medindo $20 \mathrm{~mm} \times 5 \mathrm{~mm} \times 1 \mathrm{~mm}$ sob a artéria com a função de anteparo. Após 30 minutos da administração da droga, foram provocadas três lesões contusas, com intervalo de 15 segundos,
In spite of few reports in the literature related to the use of the murine antibody against the platelet glycoprotein IIb/IIla receptor to avoid thrombosis in vascular microanastomoses (STOCKMANS et al. 1997), we ponder that the use of this drug might modify and reduce the thrombosis incidence.

In order to use the murine monoclonal antibody 7E3 abciximab - to prevent thrombosis in microsurgical procedures, we decided to test it through an experimental model in mice to evaluate its efficacy.

\section{MATERIAL AND METHODS}

A total of twenty Wistar mice were used with a mean weight of $352,37 \mathrm{~g}$ (ranging from $260 \mathrm{~g}-417 \mathrm{~g}$ ) and aged five months at the enrollment. The mice were selected into two groups of ten - Group I and Group II.

\section{Surgical Technique}

The same surgeon performed all surgeries. All animals were anesthetized with ketamine solution (Ketalarâ) $80 \mathrm{mg} / \mathrm{kg}$ plus 2\% thiazine cloridrate (Rompunâ) $3.2 \mathrm{mg} / \mathrm{kg}$ given intraperitoneally. Each animal was lying down in dorsal decubitus. The thighs and the inguinal region were shaven. Antisepsis was made using ethyl alcohol (Figure 1). An incision of 3-cm in the skin of the inguinal region between the abdomen and the thigh was performed. Femoral vascular and nervous structures were individualized and dissected. Then it was identified: the artery (centrally), the vein, (medially) and the nerve (laterally) (Figure 2). Hemostasis was performed through a bipolar electric bistoury with the aid of a surgical microscope. In the lumen of the femoral vein, a polyethylene catheter no. 24G (NIPROâ) was introduced to inject abciximab (ReoProâ) $0.8 \mathrm{mg} / \mathrm{kg}$. Group // was given the drug while Group I was given a saline solution 0.9\% (Figure 3). The same procedures were followed for the dissection of the pedicle in the opposite paw. Once the femoral artery was isolated, a plate of plastic material measuring $20 \mathrm{~mm} \times 5 \mathrm{~mm} \times 1 \mathrm{~mm}$ was placed under the artery. After 30 minutes of the drug administration, three contusion lesions were made in the femoral artery at 15-second intervals using IMPACTOR device (New York University SPINAL

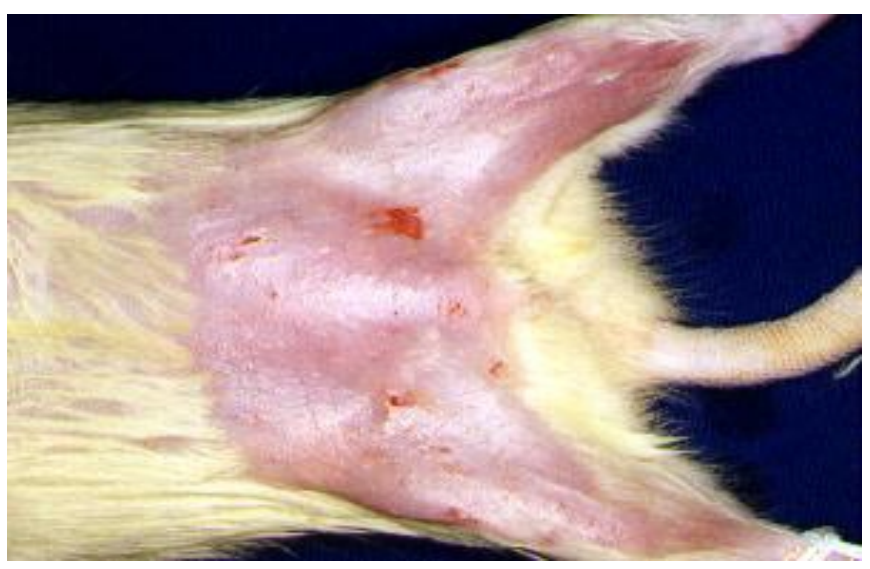

FIGURE 1. Trichotomy in the inguinal region 
na artéria femoral através do aparelho IMPACTOR (New York University SPINAL CORD CONTUSION SYSTEM) deixando o pêndulo cair de uma altura de 50 centímetros (Figura 4). A artéria, após a lesão, foi seccionada nesse local com tesoura microcirúrgica. Procedida a retirada da adventícia das bordas e, a seguir, realizada a microanastomose vascular com técnica de pontos separados com fio de náilon 10 zeros e agulha de 75 micra. Em todas as microanastomoses não foi utilizada a solução salina contendo heparina (Figuras 5 e 6).

Após o término da sutura foi observada clinicamente, a cada 10 minutos, a presença ou ausência de fluxo sangüíneo por 30 minutos da reconstrução, por meio do teste da perviabilidade com pinças microcirúrgicas de acordo com o descrito por PEDERSON; SANDERS (1999) e ACLAND (1981). As artérias femorais submetidas a microanastomoses vasculares foram removidas e os segmentos de um centímetro, cinco milímetros proximal e distal à sutura, foram imersos em solução de formol a 10\% e encaminhados ao laboratório de anatomia patológica. O anatomopatológico constou da análise das lâminas coradas por Hematoxilina-Eosina, e Verhoff e Masom. As artérias foram seccionadas transversalmente, em cortes de dois milímetros de espessura, e fixadas em formol a 10\% durante 24 horas. 0 processamento histológico ocorreu em histotécnico e o material foi emblocado em parafina. Utilizou-se um micrótomo rotativo automático para a obtenção de cinco a dez cortes de cinco micra transversais de cada artéria que foram coradas. As lâminas foram observadas no microscópio com objetivo de observar a ausência ou presença de trombos. Em seguida os ratos foram submetidos à eutanásia, administrados $100 \mathrm{mg} / \mathrm{kg}$ de pentobarbital sódico por via intraperitoneal (SOUZA, 1996). Os resultados foram avaliados por meio do teste da perviabilidade do vaso com pinças microcirúrgicas observadas ao microscópio cirúrgico (PEDERSON; SANDERS, 1999 e ACLAND, 1981) e por análise histológica da região da microanastomose vascular quanto à presença ou ausência de trombos.

Os grupos I e II foram comparados estatisticamente pelo teste de Fisher, utilizando grau de liberdade de 0,05 para significância.

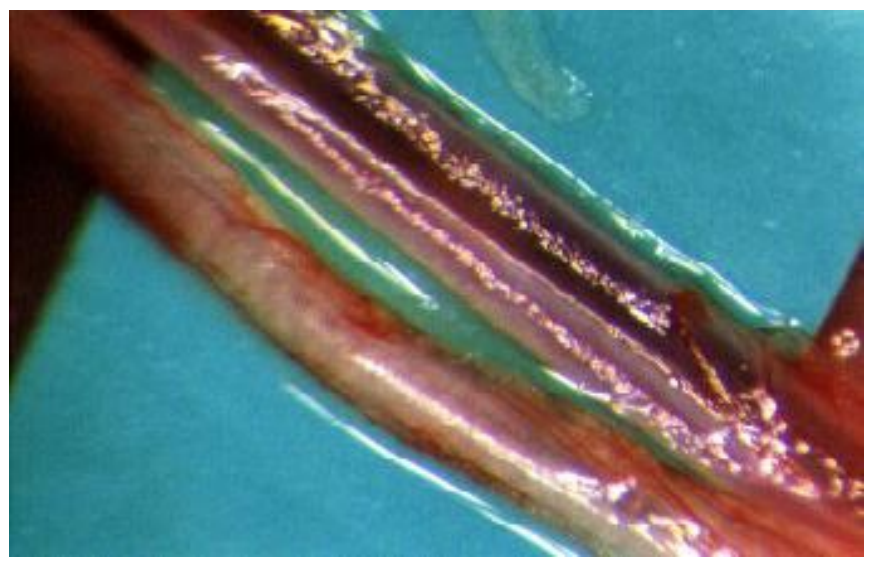

FIGURE 2. Femoral vascular and nervous bundle

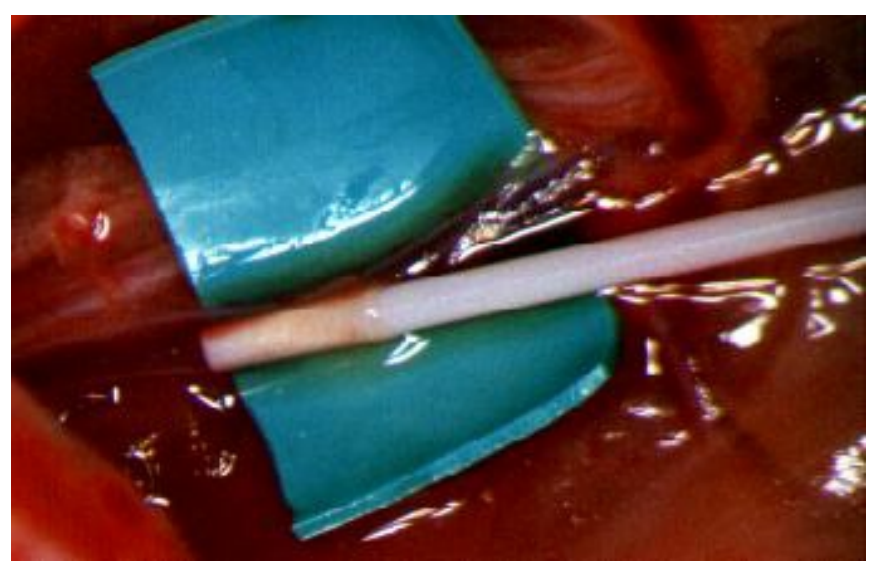

FIGURE 3. Introduction of the catheter into the femoral vein

CORD CONTUSION SYSTEM) which left the pendulum fall from a height of $50 \mathrm{~cm}$ (Figure 4). After the lesion, the artery was sectioned using microsurgical scissors. Then the vascular microanastomosis by the technique of separate points using nylon thread 10-0 and needle of 75 micra was made. In all microanastomoses the saline solution did not contain heparin (Figure 5 and 6).

After the suture conclusion, the presence or absence of blood flow 30 minutes after reconstruction was observed at each 10 min, through the test of the perviousness with microsurgical tweezers according to PEDERSON; SANDERS (1999) and ACLAND (1981). Femoral arteries underwent vascular microanastomoses were removed and immersed in formaldehyde $10 \%$ and forwarded to histological analysis. The histological analysis used hematoxylin-eosine, and Verhoff and Masom technique. Arteries were sectioned obliquely into pieces of $2 \mathrm{~mm}$ of thickness, and fixed in formaldehyde 10\% for 24 hours. The histological material was immersed in paraffin. An automatic rotative microtome was used for obtaining 5-10 pieces of 5 micra of each artery that were stained. The sheets were microscopically observed for the absence or presence of thrombi. Following this, mice were underwent euthanasia through the administration of $100 \mathrm{mg} / \mathrm{kg}$ of sodium pentobarbital intraperitoneally (SOUZA, 1996). The results were assessed through the test of the vessel perviousness using microsurgical tweezers observed at the surgical microscope (PEDERSON; SANDERS, 1999 and ACLAND, 1981) and also through histological analysis of the area of the vascular microanastomosis.

Both Groups were statistically compared through Fisher's test with 0,05 of significance.

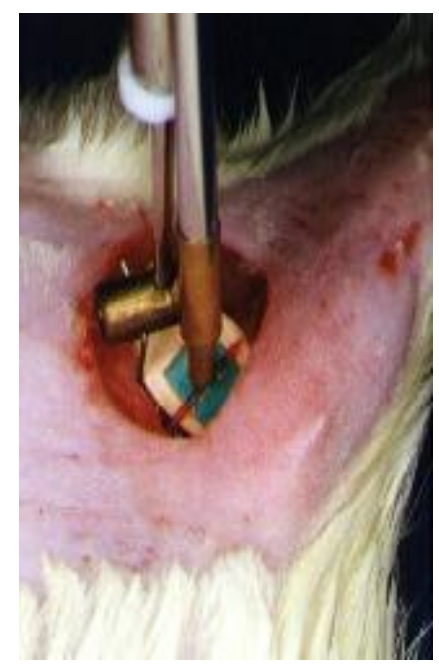

FIGURE 4. Pendulum falling on the artery causing lesion 


\section{RESULTADOS}

Avaliamos a presença de fluxo sangüíneo aos 10, 20 e 30 minutos após a microanastomoses da artéria femoral, assim como a presença de trombos no exame anatomopatológico. Conforme segue o quadro I e II.

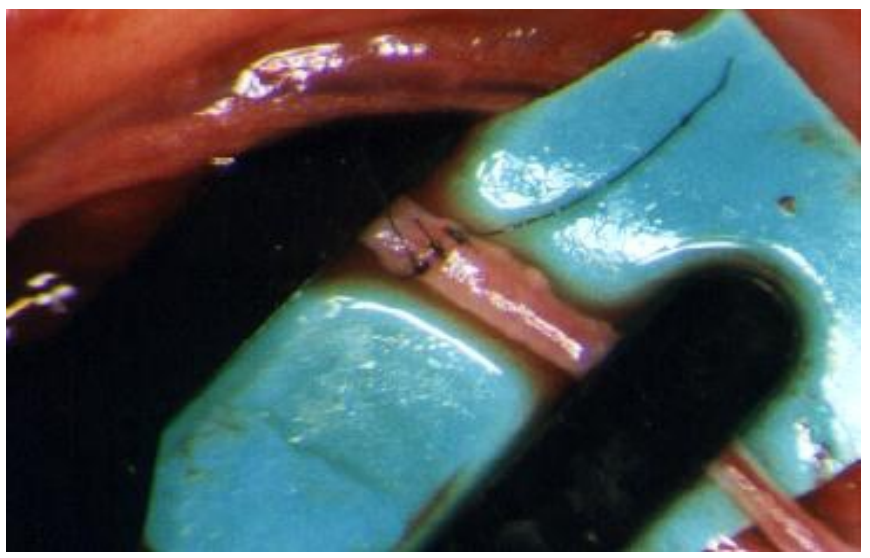

FIGURE 5. Ventral wall suture

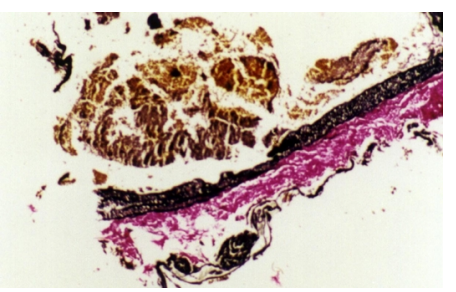

FIGURE 7. Traverse section showing the thrombus through Verhoff and Masom technique (x 200 times)

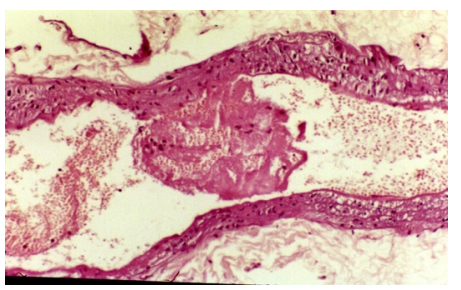

FIGURE 9. Traverse section showing the thrombus through hematoxylin-eosine technique (x 100 times)

\section{RESULTS}

We evaluated the blood flow 10,20 and 30 minutes after the microanastomoses of the femoral artery, as well as the thrombi incidence in the histological exam.

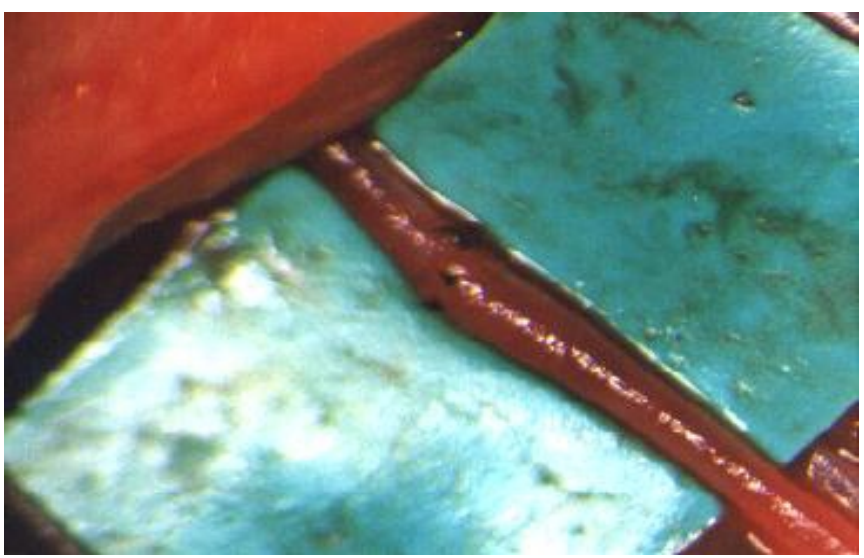

FIGURE 6. Anastomosis conclusion

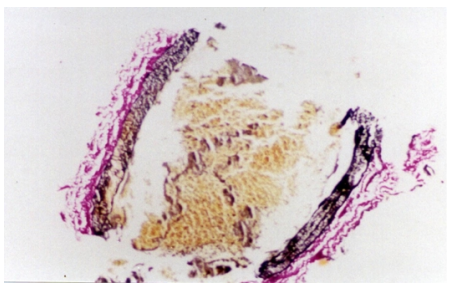

FIGURE 8. Traverse section evidencing no thrombus through Verhoff and Masom technique. Presence of blood cells (x 100 times)

FIGURE 10. Traverse section evidencing no thrombus through hematoxylin-eosine technique. Presence of blood cells (x 25 times)

CHART I - DISTRIBUTION OF THE WEIGHT AND BLOOD FLOW ANALYSIS AT 10, 20 AND 30 MINUTES AND RESULTS OF THE HISTOLOGICAL EXAM OF THE FEMORAL ARTERIES UNDERWENT VASCULAR MICROANASTOMOSES IN THE GROUP I

\begin{tabular}{cccccc}
\hline Group I & Weight & Flow 10 min & Flow 20 min & Flow 30 min & Histological Exam \\
\hline 1 & $312 \mathrm{~g}$ & PRESENT & PRESENT & ABSENT & THROMBOSIS \\
2 & $417 \mathrm{~g}$ & PRESENT & PRESENT & PRESENT & THROMBOSIS \\
3 & $409 \mathrm{~g}$ & PRESENT & PRESENT & PRESENT & NO THROMBOSIS \\
4 & $304 \mathrm{~g}$ & ABSENT & ABSENT & ABSENT & THROMBOSIS \\
5 & $349 \mathrm{~g}$ & PRESENT & ABSENT & ABSENT & THROMBOSIS \\
6 & $388 \mathrm{~g}$ & ABSENT & ABSENT & ABSENT & THROMBOSIS \\
7 & $358 \mathrm{~g}$ & PRESENT & PRESENT & PRESENT & NO THROMBOSIS \\
8 & $376 \mathrm{~g}$ & ABSENT & ABSENT & ABSENT & THROMBOSIS \\
9 & $301 \mathrm{~g}$ & ABSENT & ABSENT & ABSENT & THROMBOSIS \\
10 & $344 \mathrm{~g}$ & ABSENT & ABSENT & ABSENT & THROMBOSIS \\
\hline
\end{tabular}


CHART II - DISTRIBUTION OF THE WEIGHT AND BLOOD FLOW ANALYSIS AT 10, 20 AND 30 MINUTES AND RESULTS OF THE HISTOLOGICAL EXAM OF THE FEMORAL ARTERIES UNDERWENT VASCULAR MICROANASTOMOSES IN THE GROUP ॥

\begin{tabular}{llllll}
\hline Group II & Weight & Flow 10 min & Flow 20 min & Flow 30 min & \multicolumn{1}{c}{ Histological Exam } \\
\hline 1 & $320 \mathrm{~g}$ & PRESENT & ABSENT & ABSENT & THROMBOSIS \\
2 & $267 \mathrm{~g}$ & PRESENT & PRESENT & PRESENT & NO THROMBOSIS \\
3 & $260 \mathrm{~g}$ & PRESENT & PRESENT & PRESENT & NO THROMBOSIS \\
4 & $287 \mathrm{~g}$ & PRESENT & PRESENT & PRESENT & NO THROMBOSIS \\
5 & $330 \mathrm{~g}$ & PRESENT & PRESENT & PRESENT & NO THROMBOSIS \\
6 & $297 \mathrm{~g}$ & PRESENT & PRESENT & PRESENT & NO THROMBOSIS \\
7 & $276 \mathrm{~g}$ & PRESENT & PRESENT & PRESENT & NO THROMBOSIS \\
8 & $344 \mathrm{~g}$ & PRESENT & PRESENT & PRESENT & NO THROMBOSIS \\
9 & $268 \mathrm{~g}$ & ABSENT & ABSENT & ABSENT & THROMBOSIS \\
10 & $274 \mathrm{~g}$ & ABSENT & ABSENT & ABSENT & THROMBOSIS \\
\hline
\end{tabular}

Comparing the blood flow in the microanastomosis at 10, 20 and 30 minutes in both Groups, no statistically significant difference is observed (Table 1, 2 and 3).

TABLE 1 - DISTRIBUTION F THE BLOOD FLOW PRESENCE OR ABSENCE IN THE FEMORAL ARTERY AFTER 10 MINUTES OF MICROANASTOMOSIS

\begin{tabular}{cccc}
\hline & PRESENT & ABSENT & TOTAL \\
\hline \hline GROUP I & 5 & 5 & 10 \\
GROUP II & 8 & 2 & 10 \\
\hline TOTAL & 13 & 7 & 20 \\
\hline
\end{tabular}

Fisher's test $P=0.17492260$

TABLE 2 - DISTRIBUTION OF THE BLOOD FLOW PRESENCE OR ABSENCE IN THE FEMORAL ARTERY AFTER 20 MINUTES OF MICROANASTOMOSIS

\begin{tabular}{cccc}
\hline & PRESENT & ABSENT & TOTAL \\
\hline \hline GROUP I & 4 & 6 & 10 \\
GROUP II & 7 & 3 & 10 \\
\hline TOTAL & 11 & 9 & 20 \\
\hline
\end{tabular}

Fisher's test $P=0.18492498$

TABLE 3 - DISTRIBUTION OF THE BLOOD FLOW PRESENCE OR ABSENCE IN THE FEMORAL ARTERY AFTER 30 MINUTES OF MICROANASTOMOSIS

\begin{tabular}{cccc}
\hline & PRESENT & ABSENT & TOTAL \\
\hline \hline GROUP I & 3 & 7 & 10 \\
GROUP II & 7 & 3 & 10 \\
\hline TOTAL & 10 & 10 & 20 \\
\hline
\end{tabular}

Fisher's test $P=0.08944770$

Comparing the thrombosis incidence in the microanastomosis noted in the histological exam after 30 minutes in both Groups (Figures 17, 18, 19 and 20), a statistically significant difference was observed (Table 4).

TABLE 4 - DISTRIBUTION OF THE PRESENCE OR ABSENCE OF THROMBOSIS IN THE FEMORAL ARTERY AFTER 30 MINUTES OF MICROANASTOMOSIS

\begin{tabular}{cccc}
\hline & PRESENT & ABSENT & TOTAL \\
\hline \hline GROUP I & 8 & 2 & 10 \\
GROUP II & 3 & 7 & 10 \\
\hline TOTAL & 11 & 9 & 20 \\
\hline
\end{tabular}

Fisher's test $P=0.03488926$ 


\section{DISCUSSÃO}

Desde o início de nossas atividades no Grupo de Mão do Instituto de Ortopedia do Hospital das Clinicas da Faculdade de Medicina da Universidade de São Paulo, temos realizado vários procedimentos que necessitam de microanastomoses arteriais e venosas, como nos procedimentos de reimplantes e transferência livre de tecidos (tecido cutâneo, fascial, muscular, ósseo, etc.). Apesar da alta incidência de êxito, nossos insucessos devem-se, na maioria das vezes, à trombose das microanastomoses.

A trombose nas microanastomoses sempre se constituiu um desafio, sendo uma complicação presente mesmo quando realizada por microcirurgiões treinados e experientes. Para a sua prevenção, temos a necessidade de conhecer melhor os fatores que influenciam sua gênese.

No estudo clássico de ACLAND (1973) conclui-se que a técnica microcirúrgica atraumática pouco contribui na prevenção da trombose de microanastomose. A presença de trombos ricos em plaquetas no local da sutura (na parede, na incisão dos vasos e incisão seguida de sutura do vaso) sugere que fatores trombogênicos estejam relacionados com a lesão endotelial.

Embora alguns experimentos sugiram que o tipo de material de sutura ou os distúrbios do fluxo na região anastomosada sejam as causas principais para o desenvolvimento da trombose, DICKSON et al. (1993) e JOHNSON et al. (1992) demonstram que esses dois fatores são secundários. JOHNSON; BARKER (1992) e HILL; WHITTEN (1997) consideram que as lesões do endotélio, com a exposição do subendotélio, são as responsáveis pela gênese da trombose nas anastomoses, já que a lesão do endotélio ativa a cascata da coagulação e as plaquetas.

Dentre as substâncias anticoagulantes, a heparina atua impedindo a formação de trombina. Esta, uma vez ativada, transforma o fibrinogênio em fibrina. A heparina atua potencializando a ação da antitrombina III que inativa a ação da trombina e dos fatores de coagulação XIla, Xla, IXa e Xa. A administração da heparina pode ser pela via sistêmica, como relatam COOLEY; HANSEN (1985) e GREENBERG et al. (1988), ou localmente, cuja eficácia na prevenção de trombos é aumentada quando se adiciona a heparina na solução salina e irriga-se o vaso durante o procedimento da microanastomose vascular, como demonstram ZINBERG (1989), COX (1992) e BRAAM (1995). KOROMPILIAS (1997), em um estudo com heparina de baixo peso molecular (enoxiparina), relatam que não há maiores benefícios na administração sistêmica e tópica com relação à irrigação tópica isolada. Um problema relacionado com a administração sistêmica da heparina é a possibilidade de haver sangramento, distúrbios hemodinâmicos e formação de hematoma, causas indiretas de trombose das microanastomoses vasculares.

HUPKENS; COOLEY (1996) comparam a eficácia do anticoagulante heparina com os antiagregantes plaquetários, sendo aquele mais eficaz que estes na prevenção de trombose nas microanastomoses. Nesse trabalho os autores analisam antiagregantes plaquetários (ácido acetilsalicílico e dipiridamol)

\section{DISCUSSION}

Since our initial activities in the Hand Division of the Institute of Orthopedics from Hospital das Clínicas of the School of Medicine of São Paulo University, we have been performing a number of procedures that require arterial and venous microanastomoses. These procedures involve reimplantation and free tissue transference (cutaneous, fascial, muscular, and bony tissues). In spite the success high rates most failures occur due to microanastomoses thrombosis.

Microanastomoses thrombosis is a challenge and a common complication even for skilful surgeons and experts. For its prevention, we have to understand its pathophysiology better.

In the classical ACLAND study (1973) it was emphasized that the non-traumatic microsurgical technique contributes little for preventing the microanastomosis thrombosis. The presence of thrombi rich in platelets in the suture site (vessel walls, vessel incision and vessel incision followed by vessel suture) suggests that thrombogenic factors be related to the endothelial lesion.

Although some experiments suggest that the suture material or the disturbances of the flow in the anastomosed area are the main causes for the development of the thrombosis, DICKSON et al. (1993) and JOHNSON et al. (1992) demonstrated that both are secondary factors. JOHNSON; BARKER (1992) and HILL; WHITTEN (1997) considered that endothelial lesions with subendothelial exposure are responsible for anastomoses thrombogenicity, since the endothelial injury may activate the coagulation cascade and platelets.

Among the anticoagulant substances, heparin acts avoiding thrombin generation. Once thrombin is activated it converts fibrinogen to fibrin. Heparin enhances the activity of antithrombin III, which inactive the activity of thrombin and the clotting factors XIIa, XIa, IXa and Xa. Heparin can be administered either systemically, as described by COOLEY; HANSEN (1985) and GREENBERG et al. (1988), or topically. Its efficacy in thrombi prevention is increased when heparin is added to a saline solution and the vessel is flushed during the procedure of vascular microanastomosis, as demonstrated ZINBERG (1989), COX (1992) and BRAAM (1995). KOROMPILIAS (1997), when studied a heparin of low molecular weight (enoxaparin) reported that there are no benefits in the systemic or topical administration with relationship to the single topical irrigation. Bleeding, hemodynamic disturbs and hematomas are complications of the systemic administration of heparin, and also indirect causes of thrombosis of the vascular microanastomoses.

HUPKENS, COOLEY (1996) compared heparin and antiplatelets efficacy. Heparin is more efficacious in preventing microanastomoses thrombosis. In this trial, the authors analyzed antiplatelets (acetylsalicylic acid and dipiridamole) which do not inhibit the final pathway of the platelet aggregation, i.e., the activation of the platelet glycoprotein IIb/IIla receptors, but the pathway of the cyclooxigenase. Probably, for this reason, they obtained worse results with antiplatelets.

Glycoproteins are major structural components of the platelets' membrane, which act as receptors. Glycoprotein Ib and glycoprotein from the IIb/IIla complex are the most recognized. 
que não inibem a via final da agregação plaquetária, que é a ativação dos receptores da glicoproteína llb/llla das membranas das plaquetas, e sim a via da ciclo-oxigenase. Provavelmente, por esta razão, obtiveram piores resultados com os antiagregantes plaquetários.

As glicoproteínas são componentes estruturais importantes da membrana das plaquetas, atuando como receptores. As glicoproteínas lb e do complexo llb/llla são as mais conhecidas. A glicoproteína lb contém receptores para o fator de von Willebrand e trombina, a qual se fixa à superfície plaquetária formando uma ponte ou ligação entre a plaqueta e o colágeno do subendotélio, que também tem receptores para esse fator. A união do fator de von Willebrand à glicoproteína Ib forma um canal na membrana plaquetária, permitindo o fluxo de íons cálcio do exterior para o interior da célula. Esse aumento de cálcio ativa a glicoproteína Illb/lla, promovendo sua ligação com o fator de von Willebrand e o fibrinogênio, isto leva à agregação plaquetária (SAKARIASSEN et al., 1986). Tais descobertas implicaram um avanço importante na busca de drogas mais eficientes para inibição da agregação plaquetária.

A deficiência de glicoproteínas nas plaquetas condiciona o aparecimento de doenças plaquetárias, com conseqüente quadro hemorrágico. As mais estudadas são a síndrome de Bernard-Soulier e a chamada tromboastenia de Glanzmann. A síndrome de Bernard-Soulier caracteriza-se pela plaquetopenia e pela diminuição da glicoproteína lb da membrana, não ocorrendo a adesão das plaquetas ao endotélio lesado, advindo o quadro hemorrágico. Na tromboastenia de Glanzmann, há uma ausência dos receptores da glicoproteína llb/Illa, o número das plaquetas é normal, mas a agregação plaquetária é deficiente. Apesar da agregação defeituosa, as plaquetas têm capacidade de adesão normal ao subendotélio vascular lesado (SAKARIASSEN et al., 1986). Tais patologias ajudaram a compreender melhor os efeitos da inibição da agregação plaquetária pela utilização do anticorpo monoclonal contra os receptores da glicoproteína IIb/IIla (COLLER et al., 1983).

O ácido acetilsalicílico inibe a agregação plaquetária pela inibição da síntese de tromboxano $\mathrm{A}_{2}$ (via ciclo-oxigenase), o qual ativa o receptor glicoproteína IIb/Illa. Porém, outras substâncias como o colágeno, a adenosina difosfato, a adrenalina, a trombina e a serotonina também podem ativar o receptor da glicoproteína Ilb/Illa, desencadeando a agregação plaquetária, mesmo com a via ciclo-oxigenase bloqueada. Esta é a explicação de encontrarmos vários relatos sobre a baixa eficácia do ácido acetilsalicílico na prevenção de trombose nas microanastomoses (COOLEY; GOULD, 1987 e STOCKMANS et al., 1997).

A descoberta dos antagonistas contra-receptores de glicoproteínas Ilb/llla das plaquetas possibilita o bloqueio desse receptor, impedindo-o de ser estimulado por qualquer uma das vias, proporcionando maior eficácia na antiagregação, além de impedir a ligação com seu principal agonista, a trombina.

COLLER et al. $(1985,1986)$ desenvolvem o anticorpo monoclonal murínico 7 E3 que bloqueia a ligação do fibrinogênio com o complexo receptor da glicoproteína Illb/llla. O fragmento
Glycoprotein Ib has receptors for the von Willebrand clotting factor and thrombin, which fixes to the platelet surface forming a bridge or a connection between the platelet and the subendothelial collagen, which also has receptors for this factor. Von Willebrand factor plus glycoprotein Ib form a channel in the platelet membrane, which allows the influx of calcium ions. These increased calcium levels activate glycoprotein IIb/IIla, promoting its connection between von Willebrand factor and fibrinogen, and causing platelet aggregation (SAKARIASSEN et al., 1986). Such discoveries represented an important advance in searching for more efficient drugs to inhibit platelet aggregation.

The deficiency of glycoproteins in platelets leads to platelet diseases and bleeding. The most recognized disturbs are BernardSoulier syndrome and Thromboasthenia of Glanzmann. BernardSoulier syndrome is characterized by platelet and membrane glycoprotein Ib decreases. Platelet adhesion to the harmed endothelium does not occur, which leads to bleeding episodes. In Thromboasthenia of Glanzmann, there is lack of glycoprotein IIb/IIla receptors, number of platelets is normal, but their aggregation is deficient. In spite of the defective aggregation, platelets have normal adhesion to the harmed vascular subendothelium (SAKARIASSEN et al., 1986). Such diseases helped us to understand the effects of the inhibition of the platelet aggregation by using the monoclonal antibody against glycoproteins IIb/IIla receptors (COLLER et al., 1983).

The acetylsalicylic acid inhibits the platelet aggregation through the inhibition of the thromboxane A2 synthesis (via cyclooxigenase), which activates the glycoprotein IIb/IIla receptor. However, other substances like collagen, adenosine diphosphate, adrenaline, thrombin and serotonin may also activate the glycoprotein I/b/IIla receptor, unchaining the platelet aggregation, even if the cyclooxigenase pathway is blocked. Due to this aspect, we find several reports on the low efficacy of the acetylsalicylic acid in preventing microanastomoses thrombosis (COOLEY; GOULD, 1987 and STOCKMANS et al., 1997).

The discovery of platelet glycoproteins I/b/IIla receptor antagonists makes possible the receptor blockade, avoiding stimulation by any one of the pathways, and providing larger antiplatelet efficacy. In addition, it avoids the binding with the receptor principal agonist, thrombin.

COLLER et al. $(1985,1986)$ developed the murine monoclonal antibody 7E3, which blocks the binding of fibrinogen with the glycoprotein IIb/IIla receptor complex. The purified fragment $F$ (ab) ${ }_{2}$ is capable to block $85 \%$ of receptor sites, reducing platelet aggregation in more than $90 \%$, even in the presence of agonist substances like adenosine diphosphate, adrenaline, thrombin and collagen. Although the bleeding time is prolonged in more than 30 minutes, that author in experimental studies in dogs did not describe significant bleedings.

BATES et al. (1991) studied the preventive use of 7E3 to avoid thrombosis in coronary angioplasty in dogs, showing its high efficacy. This trial provided the use of the drug as an adjuvant in avoiding acute ischemic complications associated to the highrisk angioplasty, allowing patients to be treated by this percutaneous technique. 
purificado de $\mathrm{F}(\mathrm{ab})_{2}$ é capaz de bloquear $85 \%$ dos sítios de receptores, diminuindo a agregação plaquetária em mais de 90\%, mesmo na presença de substâncias agonistas como a adenosina difosfato, a adrenalina, a trombina e o colágeno. Embora o tempo de sangramento seja prolongado em mais de 30 minutos, complicações de sangramentos significativos não são descritas por esse autor em estudos experimentais em cães.

BATES et al. (1991) estudam a aplicação da droga 7E3 na prevenção da formação de trombose na angioplastia coronária em cães, mostrando sua alta eficácia. Esse trabalho possibilita a aplicação de tal droga como coadjuvante na prevenção de complicações isquêmicas agudas associadas à angioplastia de alto risco, permitindo aos pacientes serem tratados por essa técnica percutânea.

Recentes estudos, LINCOFF et al. (1997), ELLIS et al. (1998), GHAFFARI et al. (1998) e HAASE et al. (1999) demonstram a eficácia e a baixa incidência de efeitos colaterais do inibidor do receptor da glicoproteína IIb/Illa da membrana das plaquetas (anticorpo monoclonal murínico 7E3), denominado abciximab, em pacientes com angina instável e que são submetidos à angioplastia coronária, considerada de alto risco pela existência de placa aterosclerótica complexa, sendo que os benefícios superam os riscos inerentes de sangramento.

O objetivo deste estudo experimental foi conhecer a eficácia da droga abciximab na prevenção da formação de tromboses nas microanastomoses vasculares. Tal estudo ainda não havia sido realizado, o que nos estimulou a pesquisar o efeito da referida droga neste procedimento cirúrgico.

Para a realização do presente trabalho experimental foram utilizados ratos da raça Wistar, por serem animais de fácil manuseio, de maior disponibilidade no laboratório de microcirurgia do Instituto de Ortopedia e Traumatologia do Hospital das Clínicas da Faculdade de Medicina da Universidade de São Paulo e por serem um modelo experimental da microanastomose da artéria femoral bem conhecido (ACLAND, 1981). Obtivemos do biotério do Instituto de Ortopedia e Traumatologia da Universidade de São Paulo 20 animais de sexo indiferente, com cerca de cinco meses de idade e com peso variando de 417 gramas a 260 gramas, sendo que a média do grupo I foi 355,8 gramas e a média do grupo || de 292,3 gramas. Tal diferença no peso não deve ter interferido em nossos resultados já que a administração das drogas foi calculada e dependente do peso de cada animal. Apesar de os animais do grupo I serem relativamente maiores do que os do grupo II, não observamos diferenças em relação aos calibres dos vasos a serem anastomosados.

Todas as microanastomoses foram realizadas pelo mesmo cirurgião, para minimizar possíveis diferenças de técnica entre os atos cirúrgicos realizados.

A anestesia foi realizada com cetamina em concentração de $80 \mathrm{mg} / \mathrm{kg}$ associado à solução aquosa a $2 \%$ de cloridrato de 2(2,6-xilidino)-5,6-dihidro-4H-1,3-tiazina na concentração de $3,2 \mathrm{mg} / \mathrm{kg}$, por meio de administração intraperitoneal. Optamos pela utilização desses anestésicos por ser, em relação ao pentobarbital, mais seguro porque reduz o risco de parada
In recent studies, LINCOFF et al. (1997), ELLIS et al. (1998), GHAFFARl et al. (1998) and HAASE et al. (1999) demonstrated the platelet glycoprotein I/b/IIla receptor antagonist (murine monoclonal antibody 7E3 - abciximab) efficacy and low incidence of side effects in patients with unstable angina underwent highrisk coronary angioplasty. Benefits overcome the inherent risks of bleeding.

The objective of this experimental study was to know the efficacy of abciximab for the prevention of thromboses in the vascular microanastomoses. Such a study has not been performed yet, which stimulated us to research the effect of the referred drug in this surgical procedure.

In order to perform the present experimental work Wistar mice were used once they are an experimental model of femoral artery microanastomoses well known (ACLAND, 1981). Twenty male and female animals, aged five months, whose weight ranged from $417 \mathrm{~g}$ to $260 \mathrm{~g}$ (the mean weight of Group / was 355, $8 \mathrm{~g}$ and the mean weight of Group I/ was 292,3 g) were used. Such difference in body weights did not interfere in our results since the administration of the drugs was calculated according to the weight of each animal. In spite of Group I mice were relatively larger than Group II, we did not observe significant differences in relation to the lumen of the vessels to be anastomosed.

The same surgeon to minimize possible technical differences accomplished all microanastomoses.

The anesthesia was accomplished with ketamine $80 \mathrm{mg} / \mathrm{kg}$ plus 2\% thiazine cloridrate $3.2 \mathrm{mg} / \mathrm{kg}$, intraperitoneally. These drugs are safer than pentobarbital, once the risk of respiratory depression is lower. The anesthetic effect lasts 90 minutes on average, which is enough time to perform our studies. The association of drugs provided to use more anesthetics (50\% of the first dose) with no risk of respiratory complications and death of the animal.

In our experimental model, the femoral artery was chosen due to the easier access and lesser morbidity for animals comparing to other vessels, like the carotid artery.

The femoral vein of one of the animal's paw was dissected. Animals of Group I/ and Group I was given either the drug or saline solution intravenously, respectively. The opposite paw was used for performing microanastomoses.

According to COLLER, SCUDDER (1985), the concentrations used in mice $(0.8 \mathrm{mg} / \mathrm{kg})$ were the same ones used in dogs. In the literature, we did not find any report referring to the optimal concentration to be applied in mice to block the glycoprotein IIb/ Illa receptors effectively. AHN et al. (1999) uses abciximab 2 mg/ $\mathrm{kg}$.

In the initial project, the biomechanical laboratory and us made a "clamp" to promote the arterial injury. However, we could not pattern lesions because it as difficulty to determine the pressure which was applied, as well as the minimum time to determine the arterial injury.

In this study, the main objective of using Impactor New York University was patterning the artery injury, creating a new experimental model for thrombosis. We accomplished three subsequent traumas, which is the minimum to promote thrombi generation in 
respiratória. Os efeitos anestésicos duram em média 90 minutos, tempo suficiente para a realização de nossos estudos e, com a associação destas drogas, foi possível utilizar mais anestésicos (50\% da primeira dose) sem o risco de complicações e morte do animal.

Optamos por usar, em nosso modelo experimental, a artéria femoral pela facilidade de acesso e por haver menor morbidade para o animal em comparação à utilização de outros vasos, como a artéria carótida.

Dissecamos a veia femoral de um dos membros de cada animal como via de administração da droga endovenosa, no grupo II, e solução salina, no grupo I. O membro oposto foi utilizado para a realização das microanastomoses para evitar a interferência do fluxo da artéria femoral por possível espasmo pela manipulação ou trombose da veia.

As concentrações utilizadas nos ratos $(0,8 \mathrm{mg} / \mathrm{kg})$ seguem as mesmas concentrações aplicadas em cães de acordo com COLLER; SCUDDER (1985). Não encontramos nenhum relato na literatura pesquisada de qual seria a melhor concentração a ser aplicada em ratos para bloquear os receptores da glicoproteína Ilb/Illa em quantidade eficaz. AHN et al. (1999) utilizam o abciximab na concentração de $2 \mathrm{mg} / \mathrm{kg}$.

No projeto inicial, conjuntamente com o laboratório de biomecânica, confeccionamos um "clamp" com o objetivo de provocar a lesão arterial, porém tivemos dificuldade na padronização das lesões devido à dificuldade de determinar a pressão exercida, assim como o tempo mínimo necessário para determinar a lesão arterial.

A utilização do aparelho Impactor New York University, neste estudo, tem como objetivo principal o de padronizar, com maior eficiência, a lesão da artéria, criando um novo modelo experimental para trombose. Colocamos um anteparo plástico com a finalidade de aumentar a eficácia da lesão arterial no momento da queda do pêndulo, de uma altura de $50 \mathrm{~cm}$, sobre a artéria. Realizamos três traumas subseqüentes por observarmos que este é o número mínimo de traumas para provocar a formação de trombos na maioria das artérias dos ratos. O aparelho utilizado foi desenvolvido para padronizar a lesão da medula nervosa em ratos. Segundo RODRIGUES (1999), a queda do pêndulo a altura de $50 \mathrm{~cm}$ determina a lesão da medula de forma eficaz, julgamos esta altura sendo necessária para provocar a lesão arterial.

Durante a microanastomose arterial, em nenhum momento foi utilizada a heparina na irrigação, pois a mesma poderia inibir a formação de trombos nas artérias. Tal cuidado foi salientado por BRAAM (1995) e COX (1992).

Sabemos que, na prática clínica, ocorrem lesões dos vasos mesmo posteriormente à administração das drogas antitrombogênicas ou concomitantemente à realização de microanastomoses. A seqüência alterada neste estudo experimental - a administração da droga, observação por 30 minutos, produção da lesão arterial e, em seguida, realização da anastomose -, teve como objetivo dar tempo para que os anticorpos se ligassem aos receptores da glicoproteínas IIb/IIla das plaquetas (BATES et al., 1991). Por outro lado, o modelo most of the arteries of the mice. The device used was developed to pattern the bone marrow lesion in mice. According to RODRIGUES (1999), when a pendulum falls from $50 \mathrm{~cm}$ of height it determines bone marrow injury effectively. Thus, this height is adequate to provide the arterial lesion.

During the arterial microanastomosis, heparin was not used in the irrigation, because it could inhibit thrombi generation. BRAAM (1995) and COX (1992) emphasized such aspect.

In clinical practice, vessel lesions occur even after the administration of antithrombogenic drugs or simultaneously to microanastomoses. In this experimental trial, the main objective of the altered sequence (administration of the drug - observation for 30 minutes - arterial lesion promotion - anastomosis) was to provide antibodies to bind to platelet glycoprotein I/b/IIla receptors (BATES et al., 1991). On the other hand, the experimental model for arterial lesion was so effective that, soon after the pendulum fall, and before the microanastomosis, the thrombosis occurred within 30 minutes when abciximab was not given.

We analyzed the flow presence and the maintenance of perviousness of the artery every 10 minutes for 30 minutes. According to BOECKX (1994) and BATES (1991) after the microanastomosis, the first 30 minutes are critical for thrombus generation. Thus, 30 minutes after anastomoses, we removed the femoral arteries and performed animals' euthanasia.

The efficacy of abciximab is $80 \%$ for 120 minutes following the administration (TCHENG et al., 1994). To maintain its efficacy for a larger period, the drug should be administered as an intravenous continuous infusion for 24 hours, which is not viable in mice.

The fragment of the femoral artery that was removed included the proximal and the distal segment to the suture, which are critical areas for thrombi generation. The fragments underwent histological analyses at Institute of Orthopedics and Traumatology from São Paulo University to detect thrombi presence or absence. It was used hematoxylin-eosine technique, which was considered efficient. Other staining technique (Verhoff and Masom) was used when thrombi presence was observed to visualize it better.

We used the arterial blood flow analysis test (PEDERSON; SANDERS, 1999 and ACLAND, 1981) since this is a routine in surgical procedures and it is quite trustworthy.

We analyzed the presence or the absence of blood flow at 10, 20 and 30 minutes because this is the most critical period and to determine at which moment the thrombi generation might cause blood flow disturbances.

In the Group I, 10 minutes after the microanastomosis, there was lack of blood flow in five animals, which demonstrated that the vessel lesion might promote a fast thrombus formation. 20 and 30 minutes after the microanastomoses this number was 6 and 7, respectively. Animal number 2 showed thrombosis in spite of blood flow presence (PEDERSON; SANDERS, 1999 and ACLAND, 1981). The thrombus was probably in formation and, in spite of blood flow presence at 30 minutes, it should be absent rapidly. It is very difficult to make a clinical interpretation of the flow speed, but we know that a slow flow strong indicates thrombus formation. In the animal number 2 the formation of the thrombus might be considered late (after 30 minutes), and the histological 
experimental para lesão arterial foi tão eficaz que, após a queda do pêndulo, ocorria a trombose, antes da microanastomose, num prazo de 30 minutos, quando não era administrado o abciximab.

Analisamos a presença de fluxo e a manutenção de perviabilidade da artéria a cada 10 minutos durante 30 minutos. Segundo BOECKX (1994) e BATES (1991) os primeiros 30 minutos são os mais críticos para a formação de trombo após a microanastomose. Por esta razão, após 30 minutos das anastomoses, retiramos as artérias femorais e realizamos a eutanásia dos animais.

O abciximab apresenta eficácia de 80\% por 120 minutos após a administração (TCHENG et al.,1994). Para manter a eficácia da droga por um período maior, seria necessário a administração da droga endovenosa em bomba de infusão contínua por 24 horas, sendo este procedimento pouco viável de ser realizado em ratos.

O fragmento da artéria femoral retirado incluíu o segmento um centímetro, cinco milímetro proximal e distal à sutura, região crítica para a formação dos trombos. Os fragmentos das artérias foram encaminhados ao serviço de Anatomia Patológica do Instituto de Ortopedia e Traumatologia do Hospital das Clínicas da Faculdade de Medicina da Universidade de São Paulo para serem submetidos à análise histológica quanto à presença ou ausência de trombos. Para tanto a coloração com hematoxilina e eosina é considerada eficiente. Utilizamos outra coloração (Verhoff e Masom) quando observamos a presença de trombos, já que esta permite visualizar o trombo de forma mais adequada.

Utilizamos o teste de análise de fluxo sangüíneo da artéria (PEDERSON; SANDERS, 1999 e ACLAND, 1981) já que este é prática da rotina em procedimentos cirúrgicos e a experiência demonstra que é bastante fidedigno.

Analisamos a presença ou ausência do fluxo sangüíneo aos 10, 20 e 30 minutos por ser este o período mais crítico e por queremos determinar em que momento a formação do trombo poderia causar distúrbios de fluxo sangüíneo.

Observamos que no grupo I, aos 10 minutos após a microanastomose, o fluxo já estava ausente em cinco animais, demonstrando que a lesão do vaso provoca uma rápida formação de trombo. Este número aumentou para seis animais sem fluxo na artéria aos 20 minutos e para sete aos 30 minutos. Um fato interessante ocorreu com o animal número 2 que, apesar de interpretarmos seu fluxo arterial como presente, por meio do teste com as pinças microcirúrgicas (PEDERSON; SANDERS, 1999 e ACLAND, 1981), o exame anatomopatológico revelou a presença de trombose. Provavelmente o trombo encontrava-se em formação e, certamente, o fluxo, apesar de presente aos 30 minutos, deveria tornar-se ausente em pouco tempo. É muito difícil interpretar clinicamente a velocidade do fluxo, mas sabemos que fluxo lento indica forte indício de formação de trombo. Neste animal (número 2) a formação do trombo pode ser considerada tardia (após 30 minutos), e o exame anatomopatológico evidenciou o início de sua formação.

No grupo II somente dois animais apresentaram fluxo de artéria femoral ausente aos 10 minutos. Este número aumentou exam evidenced the beginning of its formation.

In the Group II only two animals showed lack of arterial blood flow at 10 minutes. This number increased to three animals at 20 and 30 minutes. The histological exam confirmed the test performed through microsurgical tweezers (PEDERSON; SANDERS, 1999 and ACLAND, 1981).

When we compared data obtained from Group I and Group II with relationship to blood flow presence or absence at 10,20 and 30 minutes we did not observe statistically significant differences. However, we noticed a tendency to the significance in the comparison between groups with relationship to blood flow at 30 minutes ( $p=0.089$ ). With the increased sample, we might have demonstrated the difference between Groups.

We observed a statistically significant difference with relationship to thrombi presence or absence in the histological analysis of the femoral arteries of the mice in both Groups. This means that abciximab was effective for the prevention of the thrombi formation in the femoral arteries submitted to trauma and vascular anastomosis.

We did not observe important bleeding in mice of the Group II in comparison to the Group I. However, we should consider that the surgical trauma for dissection and microanastomoses of the femoral vessels in small animals can not be enough to generate complications related with bleeding.

In this experimental model, the analysis of the efficacy of this drug evidences a new perspective in the control of the platelet aggregation for the prophylaxis of the thrombosis in vascular microanastomoses. Subsequent clinical studies will be necessary to determine the limits of this drug indication.

\section{CONCLUSION}

In this experimental model, the histological study demonstrated that the administration of the drug abciximab caused a decline in the incidence of the thrombosis in the vascular microanastomoses. 
para três animais aos 20 e 30 minutos. O exame anatomopatológico confirmou o teste do fluxo com pinças microcirúrgicas (PEDERSON; SANDERS, 1999 e ACLAND, 1981).

Ao compararmos estatisticamente os dados obtidos com os grupos I e || quanto à presença ou ausência de fluxo aos 10, 20 e 30 minutos não observamos diferenças significantes. Porém, notamos uma tendência à significância na comparação dos grupos quanto ao fluxo aos 30 minutos $(p=0,089)$ e, provavelmente, com o aumento de amostra, poderíamos ter demonstrado a diferença de comportamento destes.

Observamos uma diferença estatisticamente significante quanto à presença ou ausência de trombos na análise histológica das artérias femorais dos ratos dos grupos I e II demonstrando que a droga abciximab foi eficaz quanto à prevenção da formação de trombos nas artérias femorais submetidas ao trauma e anastomose vascular.

Não observamos sangramento importante nos ratos do grupo II quando comparamos com os do grupo I. Porém, devemos considerar que o trauma cirúrgico para dissecação e microanastomose dos vasos femorais em animais de pequeno porte pode não ser suficiente para gerar complicações relacionadas com o sangramento.

A análise da eficácia desta droga, neste modelo experimental, cria uma nova perspectiva no controle da agregação plaquetária para a profilaxia da trombose em microanastomose vasculares. Estudos clínicos posteriores serão necessários para determinar os limites de sua indicação.

\section{CONCLUSÃO}

O estudo histológico demonstrou que a administração da droga abciximab promoveu uma diminuição da incidência de trombose nas microanastomoses vasculares de artérias neste modelo experimental.

\section{REFERÊNCIAS}

ACLAND, R. Thrombus formation in microvascular surgery: an experimental study of the effects of surgical trauma. Surgery, v. 73, p. 766-71, 1973

ACLAND, R. D. Manual prático de microcirurgia. São Paulo, São Paulo, 1981 104p.

AHN, Y. K.;CHO, J. G.; PARK, W. S.; KIM, N. H.; KIM, J. W.; KIM, S. H.; CHO, J. H.; PARK, J. H.; JEONG, M. H.; PARK, J. C.; KANG, J. C. The effects of antiplatelet agents in the prevention of ventricular tachyarrhythmias during acute myocardial ischemia in rats. Jpn. Heart J., v. 40, p. 79-86, 1999.

BARNATHAN, E. S.; SCHWARTZ, J. S.; TAYLOR, L. Aspirin and dipyridamole in the prevention of acute coronary thrombosis complicating coronary angioplasty. Circulation, v.76, p. 125-34, 1987.

BATES, E. R.; MCGILLEM, M. J.; MICKELSON, J. K.; PITT, B.; MANCINI, G. B. J. A monoclonal antibody against the platelet glycoprotein llb/ IIla receptor complex prevents platelet aggregation and thrombosis in a canine model of coronary angioplasty. Circulation, v. 84, p. 2463-9, 1991.

BOECKX, W. D.; HARIBHAKTI, V. V.; BOSMANS, L. Scanning electron microscopic study of thrombus formation in an end-to side anastomosis of the rat carotid artery. J. Reconstr. Microsurg., v. 10, p. 35-8, 1994.

BRAAM, M. J.; COOLEY, B. C.; GOULD, J. S. Topical heparin enhances patency in a rat model of arterial thrombosis. Ann. Plast. Surg., v. 34, p. 148-53, 1995.

COLLER, B. S.; PEERSCHKE, E. I.; SCUDDER, L. E.; SULLIVAN, C. A. A murine monoclonal antibody that completely blocks the binding of fibrinogen to platelets produces a thrombasthenic-like state in normal platelets and binds to glycoproteins IIb and/or IIIa. J. Clin. Invest., v. 72, p. 325-38, 1983.

COLLER, B. S. A new murine monoclonal antibody reports an activation-dependent change in the conformation and / or microenvironment of the GP IIb/IIla complex. J. Clin. Invest., v. 76, p. 101-8, 1985.

COLLER, B. S.; SCUDDER, L. E. Inhibition of dog platelet function by in vivo infusion of $\mathrm{F}(\mathrm{ab})_{2}$ fragments of a monoclonal antibody to the platelet glycoprotein IIb/IIla receptor. Blood, v. 66, p. 1456-59, 1985.

COLLER, B. S.; FOLTS, J. D.; SCUDDER, L.E.; SMITH, S. R. Antithrombotic effect of a monoclonal antibody to the platelet glycoprotein Ilb/llla receptor in an experimental animal model Blood, $\mathrm{v}$. 68, p. 783-6, 1986.

COLLER, B. S.; SCUDDER, L. E.; BEER, J. Monoclonal antibodies to platelet glycoprotein Ilb/Illa as antithrombotic agents. Ann. N. Y. Acad. Sci., p. 193-213, 1991.

COOLEY, B. C.; HANSEN, F. C. Microvascular repair following local crush and avulsion vascular injury. Microsurgery, v. 6, p. 46-8, 1985.

COOLEY, B. C.; GOULD, J. S. Experimental models for evaluating anthithrombotic therapies in replantation microsurgery. Microsurgery, v. 8, p. 230-3, 1987.

COX, G. W.; RUNNELS, S.; HSU, H. S.; DAS, S. K. A comparison of heparinised saline irrigation solutions in a model of microvascular thrombosis. Br. J. Plast. Surg., v. 45, p. 345-8, 1992.

DICKSON, C. S.; GARRETT, K. O.; SHEPPECK, R.A. The effect of microvascular anastomosis configuration on platelet deposition.

Plast. Reconstr. Surg., v. 91, p. 522-7, 1993. 
ELLIS, S. G.; LINCOFF, A. M.; MILLER, D.; TCHENG, J. E.; KLEIMAN, N. S.; KEREIAKES, D.; CALIFF, R.; TOPOL, E. J. Reduction in complications of angioplasty with abciximab occurs largely independently of baseline lesion morphology. EPIC and EPILOG Investigators. Evaluation of 7E3 for the Prevention of Ischemic Complications. Evaluation of PTCA To Improve Long-term Outcome with abciximab GP Ilb/Illa Receptor Blockade. J. Am. Coll. Cardiol., v. 32, p. 1619-23, 1998.

EPIC INVESTIGATORS. Use of a monoclonal antibody directed against the platelet glycoprotein $\mathrm{Ilb} / \mathrm{llla}$ receptor in high - risk coronary angioplasty. N. Engl. J. Med., v. 330, p. 956-61, 1994.

FUSTER, V.; DYKEN, M. L.; VOKONAS, P. S.; HENNEKENS, C. Aspirin as a therapeutic agent in cardiovascular disease. Circulation, v. 87, p. 659-72, 1993.

GHAFFARI, S.; KEREIAKES, D. J.; LINCOFF, A. M.; KELLY, T. A.; TIMMIS, G. C.; KLEIMAN, N. S.; FERGUSON, J. J.; MILLER, D. P.; CALIFF, R. A.; TOPOL, E. J. Platelet glycoprotein Ilb/llla receptor blockade with abciximab reduces ischemic complications in patients undergoing directional coronary atherectomy. EPILOG Investigators. Evaluation of PTCA to Improve Long-term Outcome by c7E3 GP Ilb/Illa Receptor Blockade. Am. J. Cardiol., v. 82, p. 7-12, 1998.

GREENBERG, B. M.; MASEM, M.; MAY, J. W., Jr. Therapeutic value of intravenous heparin in microvascular surgery: an experimental vascular thrombosis study. Plast. Reconstr. Surg., v. 82, p. 463-72, 1988.

HAASE, K. K.; MAHRHOLDT, H.; SCHRODER, S.; BAUMBACH, A.; OBERHOFF, M.; HERDEG, C.; KARSCH, K. R. Frequency and efficacy of glycoprotein Ilb/llla therapy for treatment of threatened or acute vessel closure in 1332 patients undergoing percutaneous transluminal coronary angioplasty. Am. Heart J., v. 137, p. 23440, 1999

HILL, G. E.; WHITTEN C.W. The role of the vascular endothelium in inflammatory syndromes, atherogenesis, and the propagation of disease. J. Cardiothorac. Vasc. Anesth., v. 11, p. 316-21, 1997.

HUPKENS, P.; COOLEY, B. C. Comparison of arterial and venous patency in a rat model of subendothelium-stimulated thrombosis. Microsurgery, v. 17, p. 226-9, 1996

JACOBSON, J. H; SUAREZ, E. I. Microsurgery in anastomosis of small vessels. Surg. Forum, v. 11, p. 243-45, 1960.

JANG, I. K.; FUSTER, V.; GOLG, H. K. Antiplatelets. Coron. Artery Dis., v. 3, p. 1030-6, 1992

JOHNSON, P. C.; BARKER, J. H. Thrombosis and antithrombotic therapy in microvascular surgery. Clin. Plast. Surg., v. 19, p, 799-807, 1992.

JOHNSON, P. C.; GARRETT, K. O.; BRASH, J. L. Delivery of passivating proteins to suture during passage through the vessel wall reduces subsequent platelet deposition by blocking fibrinogen adsorption. Arterioscler. Thromb., v. 12, p. 727-35, 1992.

KOROMPILIAS, A. V.; CHEN, L. E.; SEABER, A. V.; URBANIAK, J. R. Antithrombotic potencies of enoxaparin in microvascular surgery: influence of dose and administration methods on patency rate of crushed arterial anastomoses. J. Hand Surg. [Am], v. 22, p. 540-6, 1997.
LEFKOVITS, J.; IVANHOE, R. J.; CALIFF, R. M.; BERGELSON, B. A.; ANDERSON, K. M.; STONER, G. L.; WEISMAN, H. F.; TOPOL, E. J. Effects of platelet glycoprotein Ilb/llla receptor blockade by a chimeric monoclonal antibody (abciximab) on acute and six- month outcomes after percutaneous transluminal coronary angioplasty for acute myocardial infarction. EPIC investigators. Am. J. Cardiol., v. 77, p. 1045-51, 1996.

LINCOFF, A. M.; CALIFF, R. M.; ANDERSON, K. M; WEISMAN, H. F; AGUIRRE, F. V.; KLEIMAN, N. S; HARRINGTON, R. A.; TOPOL, E. J. Evidence for prevention of death and myocardial infarction with platelet membrane glycoprotein $\mathrm{llb} / \mathrm{llla}$ receptor blockade by abciximab (c7E3 Fab) among patients with unstable angina undergoing percutaneous coronary revascularization. EPIC Investigators. Evaluation of 7 E3 in preventing Ischemic Complications. J. Am. Coll. Cardiol., v. 30, p. 149-56, 1997.

PEDERSON, W. C.; SANDERS, W. E. Principles of microvascular surgery. In: GREEN, D. 4. ed. Green's operative hand surgery. Philaelphia, Churchill Livingstone, 1999. p. 1094-138.

RODRIGUES, N. R. Padronização da lesão de medula espinhal em ratos Wistar São Paulo, 1999. 92p Tese (doutorado) Faculdade de Medicina, Universidade de São Paulo.

ROSENBERG, R. D.; ROSENBERG, J. S. Natural anticoagulant mechanisms. J. Clin. Invest., v. 74, p. 1-6, 1984.

SAKARIASSEN, K.S.; NIEVELSTEIN, P. F. E. M.; COLLER, B. S.; SIXMA, J. J. The role of platelet membrane gylcoproteins $\mathrm{Ib}$ and $\mathrm{Ilb} / \mathrm{llla}$ in platelet adherence to human artery subendothelium. Br. J. Haematol., v. 63, p. 681-91, 1986.

SALZMAN, E. W.; ROSENBERG, R. D.; SMITH, M. H., LINDON, J. N.; FAVREAU, L. Effect of heparin and heparin fractions on platelet aggregation. J. Clin. Invest., v. 65, p. 64-73, 1980.

SOUZA, N. L. Eutanásia. In: Comissão de Ensino do Colégio Brasileiro de Experimentação Animal, 2. ed. Manual para técnicos em biotérismo. São Paulo, 1996. p. 171-7.

STOCKMANS, F.; STASSEN, J. M.; VERMYLEN, J.; HOYLAERTS, M. F.; NYSTROM, A. A technique to investigate microvascular mural thrombus formation in arteries and veins: II. Effects of aspirin, heparin, r-hirudin, and G-4120. Ann. Plast. Surg., v. 38, p. 63-8, 1997.

TCHENG, J.E.; ELLIS, S. G.; GEORGE, B. S.; KEREIAKES, D. J.; KLEIMAN, N. S.; TALLEY, J. D.; WANG, A. L.; WEISMAN, H. F.; CALIFF, R. M.; TOPOL, E. J. Pharmacodynamics of chimeric glycoprotein $\mathrm{Ilb} / \mathrm{lll}$ a integrin antiplatelet antibody Fab $7 \mathrm{E} 3$ in high- risk coronary angioplasty. Circulation, v. 90, p. 1757-64, 1994.

ZINBERG, E. M.; CHOO, D. I.; ZOTTER, L. A. Effect of heparinized irrigating solutions on patency of experimental microvascular anastomoses. Microsurgery, v. 10, p. 103-7, 1989. 